\title{
Yapısal Aile Terapisi'nin Temel Kavramlarıyla Gelin Filminin İncelenmesi
}

\author{
$\underline{\text { Muhammed Yildiz }}$ \\ * Uzm. Psk. Dan, İstanbul Üniversitesi, Eğitim Bilimleri Enstitüsü, Rehberlik ve Psikolojik \\ Danışmanlık Anabilim Dalı, Doktora Öğrencisi, İstanbul/ Türkiye \\ E-Posta: muhammed.yildiz@ogr.iu.edu.trＯRCID: 0000-0002-0760-2333
}

Öz

Bu makalenin amacı Gelin filminin yapısal aile terapisinin temel kavramları ışı̆̆ında incelenmesidir. Araştırmada Gelin filmine konu olan olaylar yapısal aile terapisinde ortaya konan; koalisyon, sistemler, sinırlar, kuşaklararası ilişkiler-hiyerarşi, denge, esneklik, güç kavramları ve aile terapisinde incelenen fonksiyonel ve fonksiyonel olmayan aileler, geniş aile, kronik hastalığa sahip çocuğu olan aileler, ailesinden bağımsızlaşmamış evli bireyler temalarıyla incelenmiştir. Filmin değerlendirilmesi sonucunda geniş aile sistemi içerisinde yaşamaya çalışan çekirdek ailenin kendi ebeveyn ve eş alt sistemini sağhlklı bir biçimde oluşturamadığı, filme konu olan geniş ailenin katı sinırlarının aile bireyleri içinde bağımsızlaşmamış bireylerin gelişmesine neden olduğu ve fonksiyonel olmayan aile sistemini meydana getirdiği ortaya konmuştur.

Anahtar Kelimeler: Aile Terapisi, Yapısal Aile Terapisi, Gelin Filmi 
ISSN:2528-9527

E-ISSN : 2528-9535

YIl Year: 7

Cilt Volume:7

Sayı Issue : 12

Uluslararası Toplum Araştırmaları Dergisi

International Journal of Society Researches

Haziran June 2017

Makalenin Gelis Tarihi Received Date: 09/01/2017

Makalenin Kabul Tarihi Accepted Date: 30/05/2017

\title{
Examining of The Movie 'Gelin' Through Structural Family Therapy Basis
}

\begin{abstract}
This article mainly aims to examine the movie Gelin in the frame of structural family therapy basis. In the search the story of the movie is examined under the terms of structural family theraphy sych as coalition, systems, borders, relation between gaps and hierarchy, balance, flexibility and strength, functional and nonfunctional families, large families, families that have chronich illness children and the married individuals who are insistly dependant to their parents. As a result of the evaluation of the research, it is clearly pointed out that the smaller families that struggle to survive in large ones can not realize their parents and wife subsystems. One other point is that as subjected to the movie the large families cause dependant individuals and nonfunctional families.
\end{abstract}

Key Words : Family Therapy, Structural Family Therapy, Gelin Movie 


\section{Giriş}

Bu araştırmada yönetmenliğini Ömer Lütfü Akad'ın (1973) yaptığ Gelin filminde geçen olaylar yapısal aile terapisinin temel kavramlarıla incelenecektir. Yapısal terapi 1960'larda Salvador Munichin tarafından geliştirilmiş bir aile terapisi yaklaşımı olarak ortaya çıkmıştır (Carr, 2006). Kuramın temel savı aile üyelerinin iletişimlerini organize eden bir yapısının olduğudur. Ailenin işlevselliği bu yapının organizasyonuna bağlıdır. Yapıda meydana gelen sağlıksız durumlar aynı zamanda ailenin sağlığını da etkilemektedir. Yapı aile üyelerini iyi ya da kötü yönde etkilemektedir. Hiyerarşik bir yapılanmada ailedeki bireyler daha sağlıklı bir biçimde iletişim kurabilirken, iyi organize edilmemiş yapılarda bu iletişim sağlıksız olmaktadır. Organizasyondaki düzensizlikler ailenin işlevsel olmamasına neden olmaktadır (Gladding, 2011). Bu araştırmada yapısal aile terapisinin temel kavramlarıyla Gelin filmi incelenmiştir. Araştırmacılara ve aile terapisiyle ilgilenenlere, yapısal aile terapisinin bakış açısıyla, filmdeki sağlıksız ebeveyn tutumlarına ve çekirdek ailenin yaşadığı sorunlara bakarak farklı bir perspektif sunmak amaçlanmıştır.

\section{Kuramsal Çerçeve}

\section{Yapısal Aile Terapisi}

Yapısal aile terapisi, aile içi etkileşimleri anlamlandırır, ailenin üyeleri arasındaki etkileşimleri, sınırlar ve alt sistemler biçiminde inceler. Bu terapi yaklaşımının kurucusu Salvador Minuchin'dir. Temel kavramları, yapı, alt sistemler ve sınırlardır. Bu yaklaşıma göre bir ailenin yapısını ortaya koyabilmek için tüm sistemin aileyi nasıl etkilediği saptanmalıdır (Nichols, 2013).

\section{Yapısal Aile Terapisinin Temel Kavramları}

\section{Koalisyon}

Kuramın altını çizdiği kavramlardan biridir. Ailedeki bireyler arasında üçüncü bireye dönük kurulan bir anlaşmayı uzlaşmayı ifade eder. 
Koalisyonun en önemli işlevi aile üyelerinin birbirleri arasındaki problemleri bu üçüncü bireye yansıtarak kendi üzerlerindeki baskıyı azaltmaya çalışmalarıdır (Gladding, 2011). Koalisyonun işlevsel olmaması durumunda üçgenleşme ortaya çıkar. Üçgenleşmeye bir ebeveynin çocukları diğer ebeveyne karşı olarak kendi tarafına çekmesi ve bununla beraber diğer ebeveyne karşı çocukları örgütlemesi örnek olarak gösterilebilir (Nadir, 2013).

\section{Sistemler}

Ailedeki bireyler sorumluluklarını yerine getirmek üzere alt sistemleri oluştururlar. Sistemlerin alt sistemleri bulunmaktadır. Bu alt sistemler arasında bulunan sınırlar ve bu sınırların geçirgenlikleri ailenin daha sağlıklı olmasını sağlar (Nadir, 2013).

Eş Alt Sistemi: Birbirini tamamlayan iki bireyden oluşur. Sağlıklı bir eş alt sisteminde bireyler birbirlerinin rol ve fonksiyonlarına sayg1 gösterirler ve adeta bir ekibin parçası gibi hareket ederler (Gladding, 2011). Karşılıklı uyum içinde bulunması gereken eşler, diğer eşi değişik biçimde etkileyebilirler. Eşlerden biri diğerinin yeterince gelişmemiş tarafların harekete geçirebilir. Onun olumlu özeliklerini geliştirebilir. Ancak tersi durumlarda eşlerden biri diğerinin olumsuz taraflarını harekete geçirebilir (Akün, 2013).

Ebeveyn Alt Sistemi: Bu alt sistemde evdeki çocukların bakımı, eğitimi, kişisel gelişimleri için sorumluluk sahibi olan sistemi ifade eder, sadece bir anne ve babadan oluşması gerekmez (Gladding, 2011). Alt sistemlerin kimlerden oluşacağı konusu önemli bir konudur. Bazı durumlarda bir çocuk veya anneanne ya da büyükbaba, ebeveyn alt sisteminin bir parçası olabilir (Özabacı ve Erkan, 2014).

Kardeşler Arasındaki Alt Sistem: Kardeşlerin oluşturduğu alt sistemdir. Kardeşler birbirleriyle iletişim ve paylaşımda bulundukları için birbirlerine karşı bir bağlllık hissederler (Gladding, 2011). 


\section{Sinırlar}

Belirgin Sınırlar: Sağlıklı ailelerde sınırlar belirgin olmalıdır. Böylece aile bireyleri birbirinden tamamen kopmaksızın bireyselliklerini de koruyabilirler (Fışıloğlu, 1992).

Katı Sınırlar: Katı sınırlar aile içindeki bireylerin rahat bir biçimde iletişim kurmalarını kısıtlamaktadır. Bu durum aile bireylerini birbirinden koparır (Nichols, 2013).

Belirsiz Sinırlar: Belirsiz sınırların hakim olduğu ailelerde aile bireylerinde bağımsızlık ve farklılaşma yoktur, bunun yerine bağımlılık vardır. Bu tip ailelerde aile bireylerinin birbiriyle nasıl iletişim kuracağı belli değildir (Gladding, 2011). Belirsiz sinır ifadesiyle, aile bireylerinin, ailenin alt sistemlerinin ve ailelerin bütünlüğünü sağlayan duygusal engeller olarak tarif edilebilir (Nichols ve Schwartz, 1997). Tüm alt sistemler, kendi içindeki ve diğer alt sistemlerin birbiriyle etkileşimleri sağlayan kuralları içeren çeşitli sınırlarla bağlanmıştır. Sınırlar, ailedeki bireyler arasındaki yakınlığ1 ve gücü idare ederek hem ailenin hem de ailedeki alt sistemlerinin bağımsızlığını korumayı amaçlar (Minuchin, 1974).

\section{Kuşaklar Arası İlişki - Hiyerarşi}

Minuchin'e göre koalisyonları güç ve uyum ekseninde değerlendirmek gerekmektedir. Sağlıklı bir ebeveynlik sisteminin oluşması için kuşaklararası önceden çizilmiş sağlıklı sınırların varlı̆̆ına ihtiyaç vardır. Disiplin konularında ebeveynlerin birbirleriyle uyumlu bir biçimde hareket etmelerinin mutlak öneminden söz etmiş ve kabul edilmiş bir otorite figürüne bağlı olarak ortaya koyulmuş ve bir miktar esneme payına sahip olan kuralların önemini ortaya koymuştur (Nadir, 2013).

\section{Denge}

Bütün sistemler bir denge arayışı içine girerler. Tüm sistemlerinin bir dengesi bulunmaktadır. Ailenin yapısındaki denge bozulduğu zaman aile bu dengeyi tekrar sağlamak için yardım arayışı içine girebilir (Nadir, 
2013). Ailedeki fertler, açık veyahut kapalı bir şekilde ailedeki mevcut dengenin devam etmesini sağlar. Var olan dengenin devam etmesi ve bozulduğunda bu dengenin yeniden elde edilmesi ailedeki örüntüler yoluyla, ailedeki kurallar ve bireyler arasındaki iletişim tarzlarıyla mümkündür (Innes, 2002).

\section{Esneklik}

Değişen durumlar ve hayat olaylarına uyum sağlayabilmek için, aile sisteminin sahip olduğu yakınlık ve sistemin içindeki güç ilişkilerini değiştirebilme, esnetebilme becerisi şeklinde ifade edilebilir (Minuchin, 1974).

\section{Güç}

Sağlıklı ailelerde, anne ve babalar çocuklarıyla kıyaslandığında çok daha fazla bir güce sahiptirler. Sağlısız ailelerdeyse, aile sistemini oluşturan hiyerarşik yapılanmada bazı farklılıklar olduğu gözlenmektedir. Bunların içinde en yaygın olanı, anne ve babaların çocuklarını disipline etmek için yeteri kadar güce sahip olamayışlarıdır (Aponte ve Van Deusen, 1981). Aile içinde gücün anne baba yerine başka sistemlerde olması durumunda ailenin fonksiyonlarında bir işlevsizlik görülebilmektedir.

\section{Fonksiyonel ve Fonksiyonel Olmayan Aileler}

Minuchin (1974), sağlıklı aile ve sağlıksız aile kavramlarını açıklarken, dikkatleri aile yapıları üzerine çekmekte ve aile yapılarının fonksiyonel olmasını sağlıklı aileyle, aile yapılarının fonksiyonel olmaması durumunu ise fonksiyonel olmayan aile kavramiyla anlatmaktadır. Fonksiyonel olmayan aileler beş alt başlıkta incelenebilir. İç içe aileler, kopuk aileler, evine bağlı olmayan kocanın olduğu aileler, olgunlaşmamış ebeveynli aileler ve ilgisiz ebeveynli ailelerdir (Üstündağ 2015). 


\section{Geniş Aile}

Geniş ailede bir kaç nesil bir arada yaşamaktadır. Geniş ailede yakın iletişimler ve birlikte yaşamın yoğun olduğu bir aile biçimidir. Aile üyeleri arasında, cinsiyet, yaş, sosyal statü ve erkek bireyin soy çizgisi temel alınmış bir ilişki düzeni mevcuttur. Ailedeki herkes bu hiyerarşik düzene tabi olur. Ailede kuralları önceden belirlenmiş bir işbölümü, üyeler arasında bir işbirliği vardır (Taylan, 2003).

Geniş ailede ailenin tüm üyeleri bu önceden belirlenmiş kurallar çerçevesinde bir işbölümü yaparlar ve ailedeki tüm işlere katkıda bulunurlar. Ailedeki bireylerin evlilikleri sürecinde eş seçimi çoğunlukla ailenin en yaşlı üyesi tarafından yapılır. Çocukların yetiştirilmesi ve eğitimi, öncelikli olarak yaşlılar olmak kaydıyla ailedeki tüm fertlerin sorumluluğundadır (Şahin, 2011). Geniş ailenin en belirgin özelliği birden fazla kuşakların aynı mekân ve zaman diliminde bir arada oturmasıdır. Geniş aile; adetlerine, geleneklerine ve göreneklerine derinden bağlı, bireyler arasında akrabalık bağlarının oldukça güçlü olduğu bir aile biçimidir. En yaşlı birey bu geniş aile sisteminde söz sahibidir. Bu birey aynı zamanda ailenin reisidir. Toprağın mülkiyeti sadece kendindedir (Tezcan, 2010).

Eski devirlerden gelen bir yapısı olan geniş ailede, evrensel ve karakteristik özellikler vardır. Kökenlerine bakıldığında özellikle Japonya, Çin, Hindistan'da daha yaygın olarak görülmektedir. Gelenekçi bir yapıya sahip olan Türk aile yapısında da halen bile köylerde, kasabalarda, hatta metropollerde yaşayan birçok ailede geniş aileden izle bulmak mümkündür. Geniş ailede mutlak otorite ailenin en yaşlı bireyindedir. Bu genellikle baba olmaktadır. Babanın, karısı üzerinde, evlenmemiş kız çocukları üzerinde, oğulları üzerinde, oğullarının eşleri üzerinde ve torunları üzerinde tartışılmaz bir egemenliği vardır (Güler ve Ulutak, 1992).

\section{Kronik Hastalığı Olan Çocuğa Sahip Aileler}

Ailede kronik hastalık sahibi bir çocuğun bulunması ailenin atmosferini birçok açıdan etkilemektedir. Kronik hastalığın ilk öğrenildiği evrede aile bireyleri adeta bir şaşkınlık yaşarlar. Hastalığı tanıyan aile bireyleri ve hastalığını öğrenen çocuk o güne kadar hakkında bilgi sahibi olmadıkları 
ancak çok uzun bir müddet birlikte yaşamak zorunda kalacakları ve mücadele etmeyi gerektirecek olumsuz bir durumla yüzleşmek zorunda kalmışlardır. Bu evrede en çok kullanılan savunma mekanizmalarından biri inkârdır. Çocuk ve aile hastalığın yanlış olduğunu iddia edebileceği gibi, aile bireyleri hastalığın ciddiyetini tam olarak anlamamış gibi de düşünebilirler (Er, 2006).

Aileler hastalığı öğrenip yaşanılan ilk şoku atlattıktan sonra, hastalıkla ilgili kendilerini suçlama, hastalığa ilişkin kızgınlık duyarlar ve adeta hayata karşı küskünlük hissederler. Aile üyelerinin, özellikle de annenin bu olaya vereceği duygusal tepkileri ve hastalıkla ilgili inançları çocuğun ve ailenin hastalığa ilişkin geliştireceği tutumlarla yakından ilgilidir. Evdeki tüm enerji hasta olan çocuğun sorununa harcanır, özellikle bu dönemde sosyal güvenlik ve hastane masraflarının karşılanabilmesi daha büyük bir sorun olarak karşımıza çıkmaktadır. Ailenin çevresel ve sosyal güvencesinin yetersiz olması, hastalıkla ilgilenmekten dolayı aile bireylerinin kendilerine ayıracak zamanlarında meydana gelen azalmalar, ailenin sosyokültürel hayata katılımının azalması, aile içinde daha farklı sorunlara yol açar (bengisemerci.com, 2015).

Çocuktaki bu ciddi hastalık ailenin duygusal dengesini adeta bir dönüşüm ve değişime uğratır. Ailenin anksiyetesi artar. Ailedeki bu anksiyete artışılla aynı anda tepkisel davranışlarda artış ortaya çıkar. Yaşanan bu tarz davranışlar aile sisteminde mevcut dengelerin sarsılmasına olanak sağlayarak daha önceden yeterince üzerine eğilinememiş, tedavi edilememiş daha başka gizil çatışmaların ortaya çıkmasını sağlar (sosyalhizmetuzmani.org, 2015).

Aynı zamanda aile bireyleri açısından bir çocuğun ölüm sürecine şahit olmak katlanılması çok acı olan bir gerçekliktir. Ölümcül hastalığın acı veren dönemlerinde, aynı zamanda çocuğun dayanma gücünü zorlayan çok derin ağrılar ve acılar yaşanır. Bir yandan hastalığın oluşturduğu sıkıntılar diğer taraftan yaklaşan ölüm gerçeği nedeniyle aile bireylerinin yaşadığı acılar, kaygılar özellikle bu dönemde çocuk ve ailesinin uğraşması gereken yoğun duygulardır (Erden, 1995). 


\section{Ailesinden Bağımsızlaşmamış Evli Bireyler}

Bireyin büyümüş üstelik evlenmiş olmasına rağmen hayatına sürekli müdahale eden, gerek annesi gerekse de babası olsun, ebeveynlerinin varlığı, adeta kişiler arası krize sebep olacaktır (larapsikiyatri.com, 2015). Geniş aile içinde bir dizi soruna yol açan bu durumun temel nedeni ailelerimizden yeterince özgürleşememek ve farklılaşamamaktır. Yetişmiş olduğu aileden yeteri miktarda ayrışmamış kişiler kendi bireysel kimliklerini yeteri miktarda geliştirememiş olmanın yanı sıra anne ve babasının beklentilerini de sorgulayamazlar. Bu tip durumlarda birey geniş aileyi mutlu etmek için kendi beklentilerini kendi çekirdek ailesinin ihtiyaçlarını önemsemeyebilir. Bu durum hayırlı evlat ifadesiyle karşılık bulur. Ancak bu durum sağlıklı bir durum değildir. Burada işlevsel olan tutum, geniş ailenin isteklerine kendi çekirdek ailemizin fonksiyonlarında oluşturacağ olumsuz etkiyi göz önünde bulundurarak hayır diyebilmek ve anne babalarımızın bizi takdir etmelerinden ziyade kendi çekirdek ailemizin ihtiyaçlarına cevap verebilmektir. Burada altını çizeceğimiz temel nokta bireylerin sağlıklı ayrımlaşma süreçlerini tamamlamalarıdır (pakuapsikoloji.com, 2015) .

İlgili literatür incelendiğinde, TC Başbakanlık Aile ve Sosyal Araştırmalar Genel Müdürlüğü tarafından (2009) Türkiye'nin değişik bölgelerinden 12 ilden, 657'si kadın, 543'ü erkek toplam 1200 boşanmış kişiyle yapılan araştırmada, evli oldukları dönemde geniş ailede yaşamış bireylerin oranının yüzde 18 olduğu ortaya konmuştur. Geniş aileyle yaşayan çiftlerin karşılaştı̆̆ sorunlara bakıldığında, çocukların eğitim süreçleriyle ilgili sorunların \% 3.8, eşin kendi ana babasından ve ailesinden etkilenmesi \%27.8, eşin kendi ailesiyle fazla ilgilenmesi ve kendi ailesine fazla vakit ayıramaması \%3.4, eşin ailesinin, çekirdek ailenin her şeyine karışması \%26.5 olarak belirlenmiştir. Araştırmanın sonuçlarına bakıldığında geniş aileyle yaşayan bireylerde farklılaşamama problemlerinin görüldüğü, bireylerin kendi çekirdek ailesinin psikolojik süreçleriyle yeterince ilgilenemediğini söyleyebiliriz. Geniş ailede mutlak söz sahibi olan kayınbaba ve kaynana, çekirdek ailenin birçok alanda işlevlerine müdahale etmektedir. Bu müdahale alanları arasında, eşler arası ilişkiler, çocuk yetiştirme, kriz çözme, ortak kararlar alma gibi her ailede olması 
gereken süreçler yer almaktadır. Tüm bu süreçler ailenin sağlıksız olmasina neden olabilmektedir.

Geniş ailenin çekirdek aile üzerindeki etkileri yalnızca psikolojik süreçlerle ilgili olmayıp ayrıca şiddet gibi olaylarında bu tip ailelerde yaşanabileceğini gösteren çalışmalar vardır. Demirci, Günaydın, Doğan ve Aynacı'nın 2005 yılında Konya'da yaptığı araştırmada çiftlerin boşanmadan evvel nerede yaşadıklarına bakılmış, 123 (\%61.5) çiftin kendi evlerinde, 45 (\%22.5) çiftin ise kayınbaba ve kaynanayla aynı evde yaşadığı ortaya çıkmıştır. Ayrıca eşlerden 5'ine (\%8.5) kayınbaba, kaynana ve diğer aile üyeleri tarafından şiddet uygulandığı ortaya konmuştur.

\section{Filmin Öyküsü}

Gelin filmi, yönetmenliğini Ömer Lütfi Akad'ın (1973) yaptı̆̆ı başrollerini Hülya Koçyiğit, Kerem Yılmazer, Ali Şen ve Aliye Rona'nın oynadığı bir yapımdır. Filmde daha önceden babası ve abisi Yozgat'ın bir köyünden İstanbul'a göç eden bir ailenin onların yanına taşınmasını ve arkasından gerçekleşen bir dizi olay anlatılır. Dede rolünde Hacı İlyas karakterini görmekteyiz. Küçük bir bakkal dükkânında İstanbul'un varoşlarında yaşam mücadelesi veren ataerkil bir ailenin yaşam öyküsü, filmin ana temasıdır. Kadının çalışmasına karşı olan ailede tüm temalar ailenin işini büyütmesi üzerine kuruludur. Mahalle bakkallığını bırakıp İstanbul'un daha lüks semtlerinin birinde işlerini büyütmeyi hedeflemektedirler. Meryem rolünü oynayan Hülya Koçyiğit kendisini adeta çocuğuna ve kocasına adayan bir anneyi temsil etmektedir. Meryem şehre gelir gelmez feodal yapıyı sorgulayıp kadının çalışabileceğini iddia etmektedir. Bu arada Meryem'in çocuğu Osman'ın koşarken nefesi tıkanmakta ve sağlığında çok büyük problemler oluşmaktadır. Meryem kocası Veli'ye çocuğunun hasta olduğunu israrla vurguluyor, ancak aile Osman'a muska yapılarak okuyup üflenerek iyileşeceğini ifade etmektedir. Bu arada evdeki iki gelin gün boyu turşu basmakta ailenin gelirine katkıda bulunmaktadır. Aliye Rona'nın oynadığı kaynana rolü ise çok baskın bir karakteri temsil eden aynı zamanda kocasının gözünün içine bile bakmaya korkan geleneksel kültürü temsil eden bir kadın rolüdür. Osman'ın problem- 
leri iyice gün yüzüne çıkmaya başladığında hemşerileri İbrahim ve eşi fabrikadan hastaneye giderken çocuğu doktora götürmelerini tavsiye eder. Ancak kaynana buna asla izin vermez. Kaynana kendince yozlaşmaması için gelinin o kadınla görüşmesine izin vermez. Bu arada Osman bir iki havale daha geçirmiş bu durum Meryem'i içten içe rahatsız etmektedir. Meryem durumu daha önce önemsememesine rağmen bir daha kocası Veli'ye anlatır. Ancak Veli çocuğunun hastalığıyla ilgili Meryem'in uyarılarını kendi benliği ve erkek rolü için bir tehdit olarak algılar, erkekliğin güç, mutlak iktidar olduğu düşüncesi Veli'de oğlunun asla hasta olamayacağı düşüncesine neden olmuştu. İbrahim ve Güler ise çok önceden Yozgat'tan İstanbul'a göçmüş ve sosyolojik evrimsel açıdan Hacı İlyas ailesinden daha ileri düzeye ulaşabilmiş, taşra adetlerini terk etmiş modern hayat biçimine ayak uydurabilmiş bir ailedir. Dolayısıyla Güler çocuğu hastaneye götürmek için Meryem'i ikna etmeye çalışır. Ancak kaynana buna asla izin vermez çünkü geleneksel ailesini kendince İstanbul'un yarattığı tehlikelere karşı korumaya çalışmaktadır. O evden bir bireyin İstanbul'un sosyolojik düzleminde var olması, kendi sahip olduğu yerel kültürel öğelere aykırı bir tutumdu. Bu durumu geniş ailelerinin yok olması olarak düşünmekte, en ufak bir taviz vermemektedirler. Bu arada Meryem oğlunun tüm derdini tek başına üstlenmesinin yanı sıra, en küçük gelin olduğu için evdeki tüm işlere koşturmaktadır. Meryem tekrar havale geçiren Osman'ın haline dayanamaz ve doktora gitmeye karar verir. Doktora giden Meryem'i acı bir sürpriz beklemektedir. Osman'in kalbi deliktir ve ameliyat olması gerekmektedir. Bir miktar paraya ihtiyaç vardır aksi takdirde Osman'ın öleceği ifade edilir. Meryem'in dünyalar başına yıkılmıştır bir an önce eve gidecek ve para isteyecektir. Bu durumu duyan Hacı İlyas, kaynana ve kocası Veli, Meryem'e kızarlar ve Osman'a hiç bir şey olmadığını ifade ederler. Kaynana bu durumdan Meryem'i sorumlu tutar ve oğlundan gelininin haddini bildirmesini ister, ancak Veli yine de karısını savunur. Meryem'in çocukla yeteri kadar ilgilenmediği, yeteri kadar beslenmesi halinde iyileşeceği vurgulanır. Bir diğer görüsse göre de İstanbul'a yeni taşındıkları için hava değişimi olduğu düşünülmüş ve hastalık ihtimalinin zerresi bile düşünülmemişti. Ailenin sınırları çok katıdır. Meryem'in doktor ısrarları kaynanayı çileden çıkarır. "Avrat gibi avrat ol da bebene bak" diyerek üstüne bir de Meryem azarlanır. Bu arada işler büyütülmüş ve marketin sarhoşluğu ailenin bütününü sarhoş 
eden bir sürece dönüşmüştür. Veli ise bu süreçte hiçbir şekilde sesini çıkaramıyor, karısı Meryem'in feryatları ve Osman'ın geçirdiği havalelereyse adeta gözünü kapatıyordu. Çünkü Hacı İlyas bu çocuğun hasta olmadığını söylemişti ve konu kapanmıştı. Bu esnada kaynana eve şarlatan bir büyücü getirir ve Osman'a kurşun döktürür. Bu kaotik duruma daha fazla seyirci kalamayan Meryem son bir çare olarak kolundaki bilezikleri sıyırıp bozdurarak Osman'ı ameliyat ettirmeyi düşünür ancak işleri büyüttükleri için nakit paraya ihtiyaç duyan kayınbabasının acil nakde ihtiyacı olur. Kayınbabasından ilk fırsatta borçlarını ödeyip Osman'la ilgilenme sözünü alan Meryem parayı dükkânın ihtiyaçları için kayınbabasına verir. Haftalar ilerleyince Meryem değişik zaman dilimlerinde Hacı İlyas'a ameliyatı hatırlatır, ancak sürekli işini daha büyütmekten başka bir derdi olmayan aile Osman'ı adeta ölüme terk eder. Ramazan bayramında ameliyat sözü verilir, ardından bayram atlatıldıktan sonra ameliyat sözü alınır. Ancak dükkânın bitip tükenmeyen borçları, Osman'ın ameliyatını hatırlatmaya çalışan Meryem'in yüzüne bir tokat gibi vurulur. Bitmek tükenmek bilmeyen anne yüreğiyle Meryem tekrar tekrar Hacı İlyas'ın kapısını çalar, ancak ne var ki dükkânın ihtiyaçları bir türlü bitmemektedir. Bu arada Meryem ikinci çocuğuna hamile kalmıştır. Ancak Veli dükkânın sarhoşluğuyla bunu bile geç öğrenir. Meryem son kez kurban bayramına ameliyat sözü alır. Ancak bu geçen zaman diliminde hiçbir müdahale yapılmadı̆̆ı için Osman kurban bayramında vefat eder. Oğlunun acısıyla evi terk eden Meryem'den uzun süre haber alınmaz. Namusunu temizle baskısıyla eline silah verilen Veli karısını aramaya başlar. Abisi Veli'ye Meryem'in bir fabrikada çalıştığı haberini iletir. Veli elinde silahla fabrikaya gider. İzleyici Veli'nin Meryem'i öldüreceğini beklerken, Veli karısına sarılarak "Bu fabrikada bana da iş var mı" der. Ve bu sahneyle film sona erer (Akad, 1973). 
Tablo 1. Hacı İlyas Ailesinin Aile Haritası

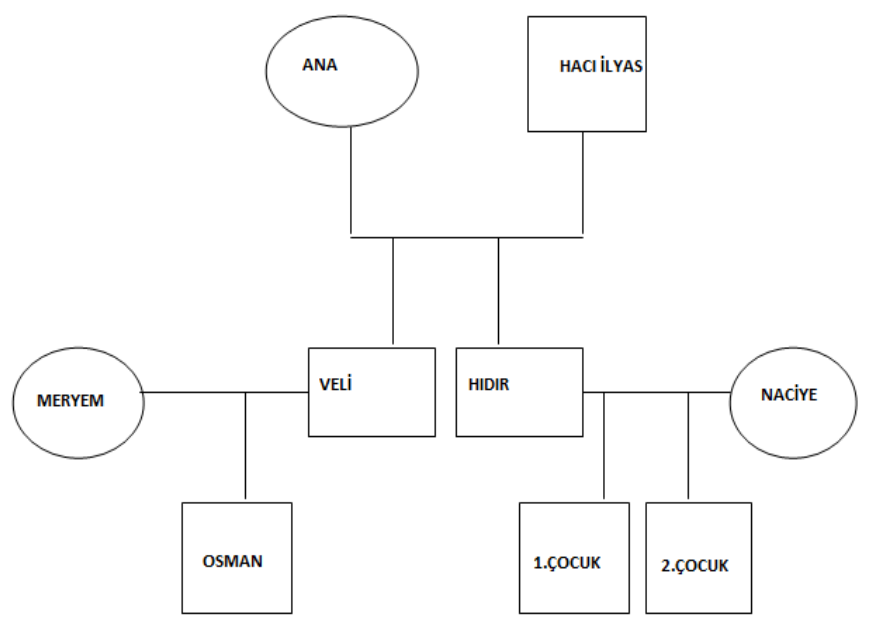

\section{Yöntem}

$\mathrm{Bu}$ araştırma nitel araştırma yöntemlerinden biri olan doküman incelemesi yöntemiyle yapılmıştır.

Filmdeki Temaların Yapısal Aile Terapisinin Temel Kavramlarıla Değerlendirilmesi

\section{Bireyin Mutluluğu, Ailenin Mutluluğu}

Geleneksel Türk aile yapısı içinde geniş aile kavramının incelendiği filmde, ailedeki tüm bireyler adeta büyük fabrikanın dişlileri gibi hareket etmekte, sofraya konan yemeğe herkes aynı anda kaşık uzatmakta, dükkânın selameti için herkes mesai sarf etmekte, ailede adeta bir koşuşturmaca yaşanmaktadır. Bu nedenle çocuğun ameliyat edilmesi bile 
sadece ailenin maddi dengeleri bozulmasin diye ertelenebilmektedir. Filmde özellikle bireysel ihtiyaçlara ve bireysel farklılıklara önem verilmediği, ailenin tüm fertlerinin ailenin ekonomik refahını artırmak için tüm bireyselliklerini ikinci plana attığı görülmektedir.

\section{Ailenin Değer Sistemi}

Ailenin değer sistemine bakıldığında, ailenin yapısıyla ilgili olarak köykent sosyolojisi bağlamında sonuçlara varılabilir. Aslen Yozgat'tan olup, taşralı bir aile olan Hacı İlyas'ın ailesi İstanbul'un arka sokaklarının birinde küçük bir bakkal dükkânında var olma mücadelesi vermektedir. Ancak modern kent yaşamında daha iyi bir yer edinebilmek için lüks semtlerde market açmak istemekte, kendi sosyal sınıflarında da iyileşme beklemektedirler. Dolayısıyla bu değer sisteminde aile, tek tek bireylerinin öznel durumlarıla ilgilenmeyip ailenin ortak menfaatlerinin peşinde koşmalarını tüm aile bireylerinden talep etmektedir. Ailede özellikle kişisel farklılıklara önem verilmeyip yerel kültüre ait öğelere değer atfedildiğini görüyoruz. Kaynana ve kayınbaba, ailenin diğer bireylerinin karısını fabrikada çalıştırdığı için hemşerileri olan çiftle görüşmesine bile tahammül etmemektedir. Çünkü kentin sosyal ve kültürel değerleriyle bezenmiş bir Meryem'in kendi menfaatleri doğrultusunda çalışmayacağını düşünmektedirler.

\section{Burası Yozgat}

Her ne kadar daha lüks bir semtte bir var oluş mücadelesi içine girilse de, filmde İstanbul makro aleminde, adeta bir Yozgat mikro alemi oluşturma çabası gözükmektedir. Aile üyeleri bireylerin sözde yozlaşmamaları için burasının İstanbul olduğunu ancak evin sınırları içinde, her ne olursa olsun Yozgat'ın kültürel dokusunun bozulmayacağını ifade etmektedirler. Erkek egemen toplumsal sisteminin en uç örneği olan filmde kaynana ve en büyük gelin bile bu sağlıksız yapıya ses çıkartmamakta, erkek egemen sistemin devam etmesine çalışmaktadırlar. Aile bireylerinin İstanbul'un sözde kendi menfaatleriyle çelişen bireysel kültürel yapısında, kendi yerel değerlerini kaybedeceklerini düşünmektedirler. Aynı zamanda gelinlerinin kadın-erkek eşitliğiyle ilgili etkilenecekleri düşüncesi, 
mevcut tahakkümlerini sürdürememe kaygısı, onları kendi yerel kültürlerini devam ettirme yoluna itmektedir.

\section{Babanın Birey Olamaması}

Veli gerçek anlamda Meryem'i sevmesine ve değer vermesine rağmen, özellikle annesiyle Meryem'in ilişkilerinde ve ameliyat konusunda babası Hacı İlyas'ın ertelemeleri karşısında adeta seyirci kalmaktadır. Burada üzerinde durulması gereken nokta geniş aile içerisinde yaşayan küçük ailelerde birey olma ve aileden ayrışma problemidir. Atasözlerimize ve deyişlerimize bakıldığında "Gölgede kalan ağacın gölgesi olmayacağı" ve "Ev içerisinde ev olmayacağı" ifadeleri bu konuda açıklayıcı bilgiler sunmaktadır. Karı kocanın birbirleriyle zaman geçirmesine, evde yemeğin ne zaman pişeceğine, üstelik kaç tane ocakta yemek pişeceğine bile geniş ailenin karıştığ ${ }_{1}$ aile sistemlerine bugün Anadolu'nun pek çok yerinde şahit olmaktayız. Özellikle bazı bölgelerimizde anne babaya ayıp olur düşüncesiyle birçok çift evliliklerinin ilk bir kaç yılını erkek tarafının evinde geçirmektedir. Bu durumda, anne babasının gözünde halen çocuk olan ve asla birey olamayan ebeveynlerin kendi eş alt sistemlerini sağlıklı bir biçimde kurabilmeleri tartı̧̧malıdır.

\section{Çocuğun Kıymeti}

Filmde bir diğer dikkat çeken nokta, ailenin ortak menfaatleri uğruna tek tek bireylerin çıkarlarının gözetilmemesi ve bunun sonucunda evlatların değersiz oluşudur. Ameliyat olması gereken çocuğun acil ihtiyaçları sırf bu yüzden dükkânın menfaatlerine kurban verilmektedir. Çocuğa bir şey olması düşüncesi hiçbir şekilde aile bireylerini rahatsız etmemekte, ortak çıkarları ve dükkânın geleceği ailenin bütün gündemini meşgul etmektedir. Ailenin en büyük kaygısı dükkânı büyütme ve geliştirme ile ilgili olmaktadır.

\section{Kadercilik}

Filmde, bireylerin hiç bir sorumluluk almayıp, kaderci anlayışla ölüm olayını takdiri ilahi olarak nitelendirmeleri göze çarpan bir diğer tema 
olarak karşımıza çıkmaktadır. Annenin bütün ısrarlarına rağmen gözlerinin önünde eriyip giden torunlarına, hiç bir sağlık önlemi almayan aile ölüm olayını hayatın normal bir seyri olarak değerlendirmiş ve elden hiç bir şey gelmeyeceği sonucuna varmıştır. Ancak filmde ilginç bir çatışma dikkat çekmektedir. Çocuğun hastalıkla ilgili belirtilerini görmelerine rağmen, işi dua ve üfürükçü çağırarak çözmeye çalışan ailede kayınbabanın ayaklarındaki ağrıyı dindirmek içinse eczaneden krem alınmaktadır.

\section{Bir Krizin Karı Kocayı Güçlendirmesi}

Aile içinde yaşanan bir krizin, aile sistemini nasıl düzene soktuğu ve yeni bir denge kurulduğunun en açık örneği oğullarını kaybeden Veli ve Meryem'in yaşadıkları ağır travmadan sonra aile baskısından kurtulup kendi çekirdek ailelerini kurmak için yeni bir arayışa gitmeleri olarak gösterilebilir. Aile sistemindeki krizlerin, ihmallerin, bitirilmemiş işlerin, konuşulmayan konuların ailenin yaşadığı bir travmayla nasıl değiştiği, ailenin güçlendiği, filmde ortaya konmaktadır.

\section{Alt Sistemler ve Sinırlar}

Ailede sınırların çok katı olduğunu görüyoruz. Veli ve Meryem'in eş alt sistemlerinin ve ebeveyn alt sistemlerinin oluşmadığını görüyoruz. Eş alt sistemi sadece salondan girilerek ulaşılabilen bir yatak odasıyla sınırlıdır. Ebeveyn alt sistemiyse çocuklarının ameliyatlarını bile babası izin vermediği için yaptırılamaması nedeniyle işlevini kaybetmiş gibi görünmektedir. Dolayısıyla filme konu olan küçük çekirdek ailenin alt sistemlerin çalışmadığını görüyoruz. Dolayısıyla Veli ve Meryem ne doğru dürüst baş başa kalmakta ne de çocuklarıyla ilgili kendi başlarına karar vermektedirler.

\section{Denge}

Filmde büyük ailenin dengesinin ailenin ekonomik anlamda iyileşmesi için gösterilen ortak çaba ve burada kaynana ve kayınbabanın mutlak otoritesiyle kurulduğunu görmekteyiz. Ancak çocuğun ölümü küçük aile sisteminin dengesini değiştirmiş, doğacak olan yeni çocuk ve Meryem'in 
bir fabrikada işe başlaması gibi tetikleyici nedenlerle Veli bu olayı adeta fırsat bilip kendi çekirdek ailesinin dengesini yakalayabilmiştir.

\section{Koalisyonlar}

Filmde göze çarpan en temel koalisyon kaynana ve büyük gelinin, küçük geline karşı kurduğu koalisyondur. Adeta bir hiyerarşik yapılanmayı anımsatan bu koalisyon biçiminde en büyük gelin, kaynanasının her davranışını onaylayıp küçük gelini hiç dikkate almayıp adeta onun karşısında bir güç olarak durmaktadır. Meryem ise hem büyük sisteme entegre olamayışı hem de eşiyle sağlıkı bir iletişim kuramayışı nedeniyle adeta yapayalnız kalmıştır.

\section{Kuşaklar Arası İlişki}

Filmde ataerkil bir aile biçiminden söz edebiliriz. İç Anadolu'dan göç etmiş ailede mutlak otorite Hacı İlyas'tır. Bu otorite filmin başından sonuna kadar adeta etkisini hiç kaybetmemiştir. Dede kendi yaşam biçimini, kendi düşünsel sistemini oğullarına da aktarmış, maddi hırslarını, hayattan beklentilerini diğer kuşaklara da aktarmıştır. Özellikle büyük ağabeyin çocukları dededen ve babalarından aktarılan değerleri, yaşam biçimini edinmiş görünmektedir.

\section{Sonuç}

Filmde genel olarak, ataerkil aile yapısı, geleneksel geniş aile, aileden farklılaşamama, alt sistemler gibi temaların yoğun olarak işlendiğini görüyoruz. Gelin filminin aile terapisi alanına söyleyeceği en etkili sözün, geniş ailenin baskısı, bireye ve bireyin oluşturduğu çekirdek aile sistemi üzerine tahakkümü ve anne babasının menfaatleri uğruna kendi ebeveyn ve eş alt sistemlerini kuramayan, bununla birlikte hiç bir zaman asla tam bir aile olamamış çiftlerin günümüz Türkiye'sinde yaşadıkları ve yaşayacakları problemler olduğu söylenebilir.

Sinemanın dili açısından bakılacak olursa çok kısa sürede bu kadar yoğun duygusal mesajın verilmesi dikkat çekebilir. Ancak boşanma, evlilik kalitesinin düşmesi, bireylerde yaşanan ruhsal problemlerin 
nedenleri gibi faktörlerin bakış açısıyla bakıldığında normal bireylerin, evli çiftlerin, aile terapistlerinin bu filmden yarar sağlayacağını söyleyebiliriz.

Ülkemizdeki birçok ailenin, artık günümüz koşullarında geniş aile biçiminde yaşamadığını, filmde geçen diyalogların günümüzde yaşanamayacağı, o günün toplumsal koşullarının bugüne genellenemeyeceği gibi karşı görüşler olabilir ya da filmin çekildiği dönemde ülkemizin içinde bulunduğu koşulların değiştiği gibi eleştiriler olabilir, ancak hiç unutulmamalıdır ki ülkemizde hala hatırı sayılı miktarda çift aileleriyle beraber ya da aynı avluda değişik binalarda kalmaktadırlar. Kendi evlatlarının kurduğu ailelere saygı göstermeyen, onların biricikliğini göz ardı eden, hala onlar üzerinde tahakküm kurmaya çalışan ebeveynlerin varlığı günümüzde de devam etmektedir. Bu durum gücün tek elde toplanmasına, kendi çocuklarının evliliklerinin kalitesinin düşmesine, hatta uzun vadede evliliklerin sonlanmasına kadar değişik biçimlerde etki göstermektedir. Ancak filmden yola çıarak tüm geniş ailelerde buna benzer olumsuz süreçlerin olduğunu iddia edemeyiz. Elbette geniş aile süreçlerinde olumlu birçok faktörün olabileceği de göz önünde bulundurulmalıdır. Bu makale sadece "Gelin" filminin senaryosu ve kurgusu bağlamında yazılmıştır. Tüm geniş aileleri işaret edecek bir genelleme asla söz konusu değildir. Geniş aileyle yaşayıp birbirine destek olan, birbirinin bireysel gelişimine katkıda bulunan, kişilerin kendi varoluşlarına saygı duyan aileler de pekâlâ söz konusudur.

Filmdeki temaların yapısal aile terapisiyle değerlendirilmesi sonucunda şu önerilere yer verilebilir. Geniş ailedeki ebeveynler, çekirdek ailenin kendi alt sistemlerini sağlıklı bir biçimde oluşturabilmesi için, onları desteklemelidir. Bireylerin var oluşlarına saygı duyulmalı, onların ailelerinin sağlıklı bir yapıya kavuşması için her türlü olanaklar sunulmalıdır. Çekirdek aileyi oluşturan ebeveynlerin geniş aileden farklılaşması, kendi başlarına var olabilmeleri için, geniş aile bireyleri imkan sağlamalıdır. Kendi kişisel hırsları, aile içinde egemenlik mücadelesi, söz hakkı kapma yarışı gibi tutumları bırakarak, evlatlarının kendi ailelerini, kendi dinamikleriyle oluşturabilmeleri, kendi başlarına kararlar verebilmeleri açısından cesaretlendirmelidir. 


\section{Kaynakça}

Akad, Ö.L. (Yönetmen) (1973). Gelin (Film). İstanbul: Erman Film.

Akün, E. (2013). Yapısal aile sistemleri kuramı bağlamında ergenlik döneminde aile yapısı ve ergenlik dönemi sorunları. Ankara Üniversitesi Dil ve Tarih Coğrafya Fakültesi Dergisi, 53(1), 85-116.

Aponte, H.J. \& Deusen, J.M.V. (1981). Structural family therapy. In handbook of family therapy. (Ed. Gurman, A.S.-Kniskern, D.P.). Bristol: Brunner Mazel.

Bengisemerci.com. (2015). Hasta çocuk. http://www.bengisemerci.com, Erişim tarihi: 06.11.2015.

Carr, A. (2006). Family therapy. Consept, process and practice. John Wiley \& Sons Ltd. England.

Demirci, Ş., Günaydın, İ.G., Doğan, K.H., \& Aynacı, Y. (2005). Konya ilindeki boşanmaların retrospektif değerlendirilmesi. Adli Tıp Dergisi Journal of Forensic Medicine Adli Tip Dergisi, 19(1), 22-28.

Er, M. (2006). Çocuk, hastalık, anne-babalar ve kardeşler. Çocuk Sağhl̆̆ı ve Hastalıkları Dergisi, 49, 155-168.

Erden, G. (1995). Ölüm sürecinde olan çocuk: Ölümü kabul ve tedavi sürecinde etkili yardım, Kriz Dergisi, 10(1), 19-27.

Fışıloğlu, H. (1992). Yapısal aile terapisi modeli ve bir vaka. Psikoloji Dergisi, 7(27), 10-14.

Gladding, S. (2011). Aile terapisi. Türk Psikolojik Danışma ve Rehberlik Derneği Yayınları, Ankara.

Güler, D., \& Ulutak, N. (1992). Aile kavramının tarihsel gelişimi ve Türk toplum yaşantısında aile. Kurgu Dergisi 11, 51-76.

Innes, M. (2002). Satir's therapeutically oriented educational process: A critical appreciation. Contemporary Family Therapy, 24(1), 35- 56.

Larapsikiyatri.com. (2015). İlişki ve evlilik terapisi. http://www.larapsikiyatri.com, Erişim Tarihi: 06.11.2015.

Minuchin, S. (1974). Families \& family therapy. Cambridge: Harvard University Press.

Nadir, U. (2013). Aile danışmanlığı eğitimlerinde popüler filmlerin kullanımı ve yapısal aile terapisi kuramı ile dalgaların prensi filminin analizi. Journal Of Society \& Social Work, 24(1). 
Nichols, M.P. (2013). Aile terapisi, kavramlar ve yöntemler (1.Bask1). İstanbul: Kaknüs Yayınları.

Nichols, M.P., \& Schwartz, R.C. (1997). Family therapy: Concepts and methods. USA: Allyn And Bacon.

Özabacı, N., \& Erkan, Z. (2014). Aile danışmanlı̆̆ı kuram ve uygulamalara genel bir bakış. 2. Baskı: Ankara. Pegem Akademi.

Pakuapsikoloji.com. (2015). Evlilikte geniş aile sorunları. http://pakuapsikoloji.com, Erişim Tarihi: 06.11.2015.

Sosyalhizmetuzmani.org. (2015). Çocuk sağhl̆̆̆. http://www.sosyalhizmetuzmani.org, Erişim Tarihi: 06.11.2015.

Şahin, H. (2011). Kitle iletişim araçlarında aile ve ataerkinin yeniden üretimi örnek olaylar: Zühal Topal'la izdivaç programı ve geniş aile dizisi. Yayınlanmamış Yüksek Lisans Tezi, Kütahya: Dumlupınar Üniversitesi Sosyal Bilimler Enstitüsü.

Taylan, H.H. (2003). Köy ailesinde aile içi ilişkiler (Selçikli köyü örneği). Yayınlanmamış Yüksek Lisans Tezi, Konya: Selçuk Üniversitesi Sosyal Bilimler Enstitüsü.

TC Başbakanlık Aile ve Sosyal Araştırmalar Genel Müdürlüğü, \& Demirkan, S.Y. (2009). Boşanma nedenleri araştırması. Başbakanlık Aile ve Sosyal Araştırmalar Genel Müdürlüğü Yayınları.

Tezcan, M. (2010). Sosyolojiye giriş. Anı Yayınları, 5. Baskı, Ankara.

Üstündağ, A. (2015). Yapısal aile danışmanlığı ve bir olgu örneği. Sosyal Politika Çalışmaları Dergisi, 14(33), 113-126.

\section{Kaynakça Bilgisi / Citation Information}

Yıldız, M. (2017). Yapısal Aile Terapisi'nin Temel Kavramlarıyla Gelin Filminin İncelenmesi, OPUS - Uluslararası Toplum Araştırmaları Dergisi, 7(12), 157-176. 